\title{
SISTEM PENDUKUNG KEPUTUSAN PEMILIHAN SEPEDA MOTOR BEKAS DENGAN METODE AHP DAN SAW (Studi Kasus: Sahabat Motor)
}

\author{
Nur Alam Arifin \\ Program Studi Teknik Informatika, Universitas Indraprasta PGRI \\ alamarifin@gmail.com
}

Submitted October 26, 2020; Revised November 17, 2020; Accepted November 25, 2020

\begin{abstract}
Abstrak
Pembeli sepeda motor bekas dalam menentukan pilihannya, tentu didasarkan pada beberapa kriteria yang dijadikan patokan dalam pemilihan sepeda motor bekas antara lain tahun pembuatan, kapasitas mesin, warna, tipe, dan harga. Kriteria tersebut menjadi pertimbangan untuk membeli sepeda motor bekas, berbagai pertimbangan dilakukan oleh pembeli agar mendapatkan sepeda motor bekas yang baik dan bagus. Pemilihan terhadap sepeda motor bekas yang akan dibeli ternyata tidaklah mudah bagi calon pembeli yang belum memahami seluk beluk kendaraan sepeda motor bekas. Kesulitan dalam pemilihan sepeda motor bekas maka perlu suatu rujukan sebagai dasar pemikiran dalam pemilihannya. Sistem pendukung keputusan menawarkan solusi untuk rujukan dalam pemilihan sepeda motor bekas. Sistem pendukung keputusan yang ditawarkan menggunakan AHP dan SAW dalam menyelesaikan persoalan. Persoalan bisa diselesaikan dengan menggunakan sistem perangkingan berdasarkan bobot global. Pembeli dapat memilih sepeda motor bekas berdasarkan rujukan atau rekomendasi dari sistem pendukung keputusan yang dijalankan oleh pakar. Sistem tersebut dapat membantu calon pembeli dengan memberikan hasil alternatif pilihan sepeda motor bekas yang diperoleh dari perhitungan AHP dan SAW. Berdasarkan hasil perhitungan faktor kriteria-kriteria penilaian yang diajukan ke sistem maka penentuan sepeda motor bekas diperoleh melalui perhitungan nilai bobot prioritas untuk pemilihan alternatif sepeda motor bekas yang akan dibeli. Dengan adanya Sistem Pendukung Keputusan untuk memilih sepeda motor bekas menggunakan metode AHP dan SAW diharapkan dapat membantu calon pembeli dalam pemilihan sepeda motor bekas dan dapat menghasilkan suatu hasil optimal yang memenuhi rasa kepuasan yang tinggi bagi calon pembeli sepeda motor bekas.
\end{abstract}

Kata Kunci : SPK, Pembeli, Sepeda Motor Bekas, AHP, SAW

\begin{abstract}
Buyers of used motorbikes in determining their choices, of course, are based on several criteria that are used as benchmarks in selecting used motorbikes, including the year of manufacture, engine capacity, color, type and price. These criteria are a consideration for buying a used motorbike, various considerations are made by the buyer in order to get a good and good used motorbike. The selection of used motorbikes to be purchased is not easy for prospective buyers who do not understand the ins and outs of used motorbikes. The difficulty in selecting used motorbikes requires a reference as a rationale for selecting used motorbikes. The decision support system offers a solution for referral in the selection of used motorbikes. The decision support system offered uses AHP and SAW in solving problems. Problems can be solved by using a ranking system based on global weights. Buyers of used motorbikes can choose used motorbikes based on referrals or recommendations from a decision support system run by experts. This system can help prospective buyers by providing alternative results for the choice of used motorbikes obtained from AHP and SAW calculations. Based on the calculation of the assessment criteria factors proposed to the system, the determination of used motorbikes is obtained through the calculation of priority weight values for the alternative selection of used motorbikes to be purchased. With the Decision Support System to choose a used motorbike using the AHP and SAW method, it is hoped that it can help prospective buyers in selecting used motorbikes and can produce optimal results that meet a high sense of satisfaction for prospective used motorcycle buyers.
\end{abstract}

Keywords: SPK, Buyer, Used Motorcycle, AHP, SAW 


\section{PENDAHULUAN}

Kendaraan sepeda motor merupakan salah satu alat transportasi yang banyak dibutuhkan oleh masyarakat karena sepeda motor dapat memberikan mobilitas yang baik di daerah yang macet. Sepeda motor merupakan salah satu kebutuhan primer, ini berlaku untuk masyarakat ekonomi kelas menengah. Dimana sepeda motor sekarang bukanlah barang langka, dan bagi kaum yang memiliki uang sedikit berlebih merupakan sebuah kebutuhan yang harus dipenuhi karena fungsi dari sepeda motor sangatlah bermanfaat.

Bagi sebagian masyarakat seringkali mengalami kendala untuk membeli sepeda motor baru karena keterbatasan ekonomi, sehingga memilih membeli sepeda motor bekas. Sepeda motor bekas merupakan sepeda motor yang pernah dimiliki oleh orang lain. Harga sepeda motor bekas umumnya lebih murah daripada sepeda motor baru dan dijual melalui showroom sepeda motor bekas atau ditawarkan secara langsung oleh pemiliknya. Jenis sepeda motor bekas yang dijual di showroom antara lain jenis bebek, sport, dan sekuter matic dari berbagai merk dan tahun.

Maka dalam hal itu, penulis akan membuat sebuah analisa sistem untuk pemilihan sepeda motor bekas di showroom sahabat motor berbasis Sistem Pendukung Keputusan dengan metode AHP dan SAW, penerapan metode AHP yang dikombinasikan dengan SAW dalam sistem pengambil keputusan ini diharapkan dapat membantu pembeli dalam menentukan sepeda motor bekas yang baik dan bagus.

Sistem pendukung keputusan pemilihan sepeda motor bekas berbasis website ini dibutuhkan oleh showroom Sahabat Motor tidak hanya untuk membantu sales namun juga dapat dimanfaatkan oleh calon pembeli. Bagi sales, kecepatan layanan informasi yang diberikan diharapkan dapat mempengaruhi pelanggan untuk membeli sepeda motor bekas sehingga akan menguntungkan pemilik showroom, karena dengan demikian omset atau keuntungan penjualan akan meningkat. Sebaliknya apabila layanan informasi yang diterima pelanggan terlalu lama dikhawatirkan calon pembeli akan beralih ke showroom lain. Sementara bagi pelanggan, aplikasi berbasis website dapat dimanfaatkan untuk mendukung keputusan pemilihan sepeda motor bekas yang sesuai dengan keinginan dan kebutuhan pelanggan. Selain itu, showroom Sahabat Motor juga dapat mengkolaborasikan metode SAW dengan metode lain seperti AHP guna membantu meningkatkan omset ataupun menarik dan membantu konsumen dalam pengambilan keputusan untuk membeli kendaraan seprda motor bekas.

\section{Sistem Pendukung Keputusan}

Sistem pendukung keputusan merupakan sistem informasi interaktif yang menyediakan informasi, pemodelan, dan manipulasi data. Sistem itu digunakan untuk membantu pengambilan keputusan dalam situasi yang semiterstruktur dan situasi yang tidak terstruktur, dimana tak seorang pun tahu secara pasti bagaimana keputusan seharusnya dibuat [1].

\section{Metode Analytical Hierarchy Process (AHP)}

AHP merupakan suatu model analisa yang menggunakan pikiran yang teratur atau sekelompok pikiran dalam proses dalam proses bekerjanya untuk menghadapi kompleksitas yang ditangkapnya. Dengan menggunakan AHP, suatu persoalan akan diselesaikan dalam suatu kerangka pemikiran yang terorganisir, sehingga dapat diekspresikan untuk mengambil keputusan yang efektif atas persoalan tersebut. Persoalan yang kompleks dapat disederhanakan dan dipercepat proses pengambilan keputusannya. 
Marimin menjelaskan bahwa prinsip kerja AHP adalah merupakan penyederhanaan suatu persoalan kompleks yang tidak terstruktur, strategis, dan dinamik menjadi sebuah bagian -bagian dan tertata dalam suatu bentuk struktur keputusan hierarki. Tingkat kepentingan setiap variabel diberi nilai numerik, secara subjektif tentang arti penting variabel tersebut dan relatif dibandingkan dengan variabel yang lain. Dari berbagai pertimbangan kemudian dilakukan sintesa untuk menetapkan variabel yang memiliki prioritas tertinggi dan berperan untuk mempengaruhi hasil pada sistem tersebut. Sehingga dapat diartikan bahwa AHP merupakan model analisa subjektif dalam proses pengambilan keputusan berdasarkan beberapa atribut dalam sistem struktur keputusan yang hierarki.[2].

AHP merupakan sebuah model yang cukup fleksibel untuk membantu dalam proses pengambilan keputusan, pengamatan mendasar ini tentang sifat manusia, pemikiran analitik, dan pengukuran yang membawa pada pengembangan suatu model yang berguna untuk memecahkan persoalan secara kuantitatif. Proses hierarki analitik yang dibangun di dalamnya adalah model yang cukup fleksibel untuk memberikan kesempatan bagi perorangan atau kelompok untuk membangun gagasan-gagasan dan mendefinisikan persoalan dengan cara membuat asumsi mereka masing-masing dan memperoleh pemecahan yang diingikan darinya.[2].

\section{Metode Simple Additive Weighting (SAW)}

Metode SAW sering dikenal dengan istilah motode penjumlahan terbobot [3]. Konsep dasar metode SAW adalah mencari penjumlahan terbobot dari rating kinerja pada setiap alternatif pada semua atibut[4]. Adapun langkah-langkah penyelesaian SAW sebagai berikut :
1. Menentukan kriteria-kriteria yang akan dijadikan acuan dalam pengambilan keputusan, yaitu $\mathrm{Ci}$.

2. Menentukan rating kecocokan setiap alternatif pada setiap kriteria.

3. Membuat matriks keputusan berdasarkan kriteria $(\mathrm{Ci})$, kemudian melakukan normalisasi matriks berdasarkan persamaan yang disesuaikan dengan jenis atribut (atribut keuntungan ataupun atribut biaya) sehingga diperoleh matriks ternormalisasi R.

4. Hasil akhir diperoleh dari proses perankingan yaitu penjumlahan dari perkalian matriks ternormalisasi $\mathrm{R}$ dengan vector bobot sehingga diperoleh nilai terbesar yang dipilih sebagai alternatif terbaik (Ai) sebagai solusi [5].

Formula untuk melakukan normalisasi tersebut adalah sebagai berikut :

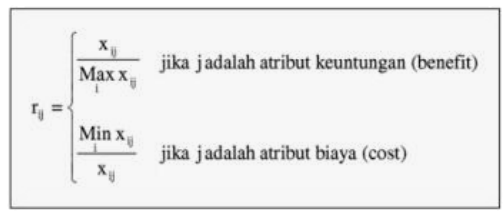

Keterangan :

rij = Nilai rating kinerja

xij $=$ Nilai kinerja dari setiap rating

Max xij= Nilai terbesar dari tiap kriteria Min $x i j=$ Nilai terkecil dari tiap kriteria

Dengan rij adalah rating kinerja ternormalisasi dari alternatif $\mathrm{Ai}$ pada atribut $\mathrm{Cj} ; \mathrm{i}=1,2, \ldots \mathrm{m}$ dan $\mathrm{j}=1$, $2, \ldots$. . Nilai preferensi setiap alternatif (Vi) diberikan pada persamaan II.

$\mathrm{Vi}=\sum \mathrm{j}^{\mathrm{n}}=1$ wjrij .... persamaan (II)

Dimana :

$\mathrm{Vi}=$ Nilai aknir dari alternatif

wj = Bobot yang telah ditentukan

rij $=$ Normalisasi nilai matriks

Nilai Vi lebih besar mengindikasikan bahwa alternatif Ai lebih terpilih [6]. 


\section{PHP}

PHP adalah bahasa yang dirancang secara khusus untuk penggunaan pada web. PHP adalah tool untuk pembuatan halaman web dinamais (php.net, 2015). Kaya akan fitur yamg membuat perancangan web dan pemprograman lebih mudah. PHP digunakan pada 13 juta domain. PHP kependekan untuk Hypertext Processor. Pada awal pengembangannya oleh pengembangannya oleh Rasmus Lerdorf, dia meneyebutkan sebagai Toll Personal Home Page. Sintaks bahasa PHP adalah sama seperti sintaks C. PHP lebih sederhana dibandingkan $\mathrm{C}$ karena tidak menggunakan sebagian dari $\mathrm{C}$ yang sulit.

Seperti bahasa pemrograman web lainnya PHP memproses seluruh perintah yang berada dalam skrip PHP di dalam web server dan menampilkan output-nya ke dalam web broser client. PHP adalah bahasa scipting yang menghasilkan output HTML ataupun output lain sesuai keinginan pemprogram yang dijalankan pada server side. Artinya, semua sintaks yang kita berikan akan sepenuhnya dijalankan pada server sedangkan yang dikirimka ke browser hanya hasilnya saja.

\section{MySQL}

MySQL adalah salah satu jenis database server yang sangat terkenal dan banyak digunakan untuk membangun aplikasi web yang menggunakan database sebagai sumber dan pengolaham datanya". MySQL dikembangkan oleh perusahaan Swedia bernama $M y S Q L$ AB yang pada saat ini bernama Tcx Data Konsult AB sekitar tahun 1994-1995, namun cikal bakal kodenya sudah ada sejak tahun 1979. Awalnya Tcx merupakan perusahaan pengembang software dan konsultan database, dan saat ini MySQL sudah diambil alih oleh Oracle Corp. Kepopuleran $M y S Q L$ antara lain karena $M y S Q L$ menggunakan $S Q L$ sebagi bahasa dasar untuk mengakses databasenya sehingga mudah untuk digunakan, kinerja quary cepat dan mencukupi untuk kebutuhan database perusahaanperusahaan yang berskala kecil sampai menengah, $M Y S Q L$ juga bersifat open source (tidak berbayar) [7].

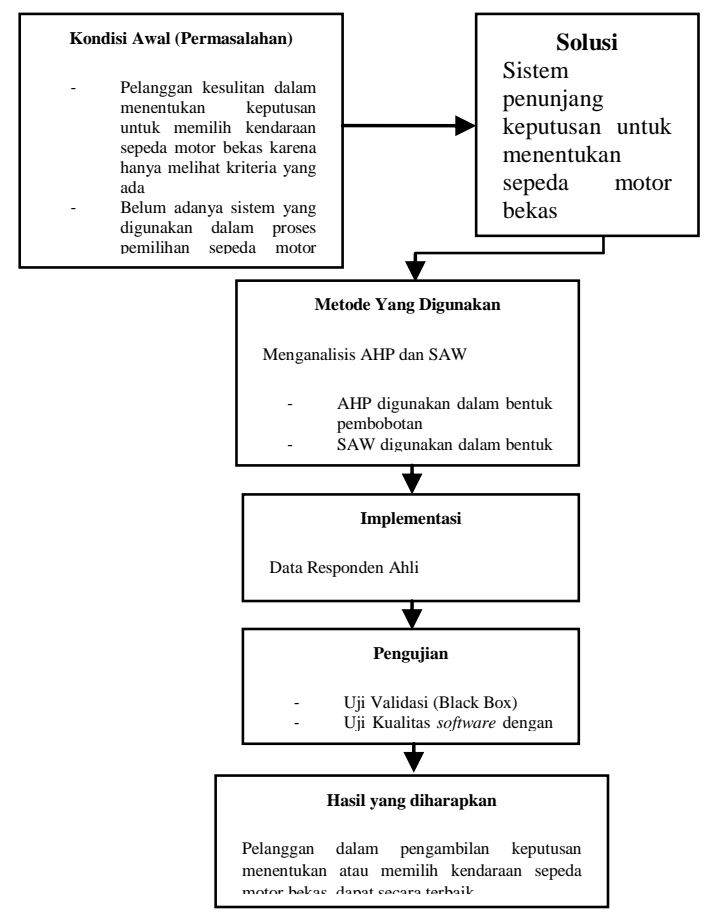

Gambar 1. Kerangka Konsep/Pola Pikir Pemecahan Masalah

\section{METODE PENELITIAN}

\section{Metode Penelitian}

Metodologi penelitian yang dipakai dalam model sistem pengambilan keputusan pemilihan pembelian sepeda motor bekas menggunakan metode kuantitatif. Kriteriakriteria yang ada sudah ditentukan sejak awal penelitian, dimana satu atau lebih faktor divariasikan dan faktor lain yang dibuat konstan.

\section{Metode Pemilihan Sampel}

Dalam pemilihan sampel digunakan metode Sampling Non Random Purposive, dimana kriteria sampel ditetapkan terlebih dahulu, sampel diambil yang memenuhi kriteria saja. Sampel yang dipilih pada penelitian ini adalah masyarakat umum di Tangerang Selatan. 
Jenis penelitian yang dilakukan adalah jenis penelitian informasi kuantitatif yaitu pengambilan data yang telah dikumpulkan oleh showroom Sahabat Motor Tahun 2013-2017. Berikut merupakan data calon pembeli yang berminat dan pembeli sepeda motor bekas:

Tabel 1. Data Calon Pembeli dan Pembeli Rentang Tahun 2013-2017

\begin{tabular}{ccc}
\hline Tahun & $\begin{array}{c}\text { Jumlah } \\
\text { Calon } \\
\text { Pembeli }\end{array}$ & Pembeli \\
\hline 2013 & 175 & 75 \\
2014 & 120 & 75 \\
2015 & 132 & 80 \\
2016 & 183 & 80 \\
2017 & 164 & 70 \\
\hline Jumlah & $\mathbf{7 7 4}$ & $\mathbf{3 8 0}$ \\
\hline
\end{tabular}

\section{Metode Pengumpulan Data}

Metode pengumpulan data [6] yang digunakan peneliti dalam merancang sistem pendukung keputusan pemilihan sepeda motor bekas sebagai berikut :

1. Studi Pustaka, yaitu pengumpulan data yang diperoleh dari literatur yang berhubungan dengan masalah yang diteliti.

2. Wawancara, yaitu dengan melakukan tanya jawab dan bertatap muka langsung dengan pihak yang berkaitan langsung dengan sistem pendukung keputusan pembelian sepeda motor bekas, dalam hal ini Sahabat Motor sebagai obyek penelitian dan sumber informasi penelitian, sehingga pengumpulan data dan informasi akan lebih relevan dan akurat.

3. Kuesioner, yaitu membuat daftar pertanyaan tertulis yang telah disusun sebelumnya, kemudian membagikannya kepada responden, yaitu masyarakat luas dan Sahabat Motor.
Data dalam penelitian ini terdiri dari:

a. Data Primer

Adalah data yang diperoleh secara langsung dari sumber, laporanlaporan pembelian kendaraan sepeda motor bekas tahun 2013 - 2017.

b. Data Sekunder

Adalah data yang diperoleh secara tidak langsung, misalnya dari literatur, dokumentasi, buku, jurnal dan informasi lainnya yang berhubungan dengan masalah pendukung keputusan dalam pembelian sepeda motor bekas.

\section{Langkah-Langkah Penelitian}

Langkah-langkah dalam penelitian merupakan rangkaian prosedur yang harus dijalani tahap demi tahap supaya sesuai apa yang menjadi tujuan. Dengan langkah langkah penelitian yang telah tersusun dengan baik maka diharapkan segala aktivitas dan kegiatan penelitian dapat terprogram dengan baik pula. Mudah dalam evaluasi dan melengkapi serta memperbaiki apabila ada hal-hal yang memang harus disempurnakan demi tujuan tersebut. Langkah-langkah penelitian harus dilaksanakan dengan urut dan struktur sesuai dengan SOP masing-masing. Dengan langkah yang urut dan terstruktur ini harus diselesaikan mulai dari awal hingga akhir proses. Selain menjalankan prosedur yang telah dibuat dengan SOP, wawancara, mengumpulkan data-data yang digunakan dalam memecahkan masalah tersebut. Dan setiap langkah-langkah penelitian didokumentasikan. 


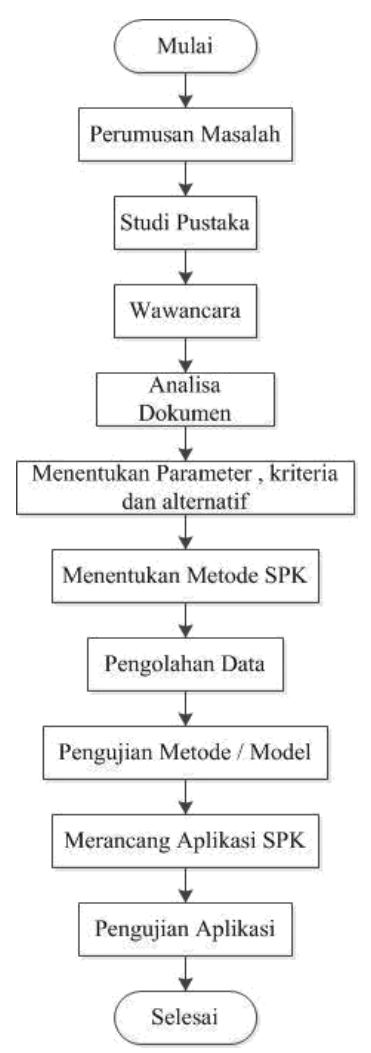

Gambar 2. Langkah-langkah Penelitian

\section{HASIL DAN PEMBAHASAN}

\section{Teknik Analisis Metode AHP}

Terdapat tiga prinsip utama dalam pemecahan masalah dalam AHP (Analytical Hierarchy Process), yaitu: Decomposition, Comparative Judgement dan Logical Concistency. Secara garis besar prosedur AHP (Analytical Hierarchy Process) meliputi tahapan sebagai berikut:

1. Dekomposisi masalah;

2. Penilaian/pembobotan untuk membandingkan elemen-elemen;

3. Penyusunan matriks dan uji konsistensi;

4. Penetapan prioritas pada masing-masing hirarki;

5. Sintesis dari prioritas; dan

6. Pengambilan/penetapan keputusan.

\section{Teknik Analisis Metode SAW}

Metode SAW (Simple Additive Weighting) sering juga dikenal istilah metode penjumlahan terbobot. Konsep dasar metode SAW (Simple Additive Weighting) adalah mencari penjumlahan terbobot dari rating kinerja pada setiap alternatif pada semua atribut. Metode SAW (Simple Additive Weighting) membutuhkan proses normalisasi matriks keputusan (X) ke suatu skala yang dapat diperbandingkan dengan semua rating alternatif yang ada.

Tahapan Metode SAW (Simple Additive Weighting)

1. Menentukan kriteria-kriteria yang akan dijadikan acuan dalam pengambilan keputusan yaitu $\mathrm{C} 1$.

2. Menentukan rating kecocokan setiap alternatif pada setiap kriteria.

3. Membuat matriks keputusan berdasarkan kriteria (C1), kemudian melakukan normalisasi matriks berdasarkan persamaan yang disesuaikan dengan jenis atribut sehingga diperoleh matriks ternormalisasi R.

4. Hasil akhir diperoleh dari proses perankingan yaitu penjumlahan dari perkalian matriks ternormalisasi $\mathrm{R}$ dengan vector bobot sehingga diperoleh nilai terbesar yang dipilih sebagai alternatif terbaik (A1) sebagai solusi.

\section{Penentuan Kriteria Pemilihan Sepeda Motor Bekas}

Pemberian nilai bobot data kriteria mengacu pada penelitian sebelumnya dengan judul Implementasi Metode Simple Additive Weighting (SAW) pada Sistem Pengambilan Keputusan Sertifikasi Guru (Indrawaty, Andrian dan Prasetya, 2011) yang menjelaskan bahwa bobot perhitungan SAW jumlah nilai bobotnya 1 atau 100. Data kriteria dapat dilihat pada tabel 2 .

Tabel 2. Data Kriteria

\begin{tabular}{cccc}
\hline No & Kriteria & Atribut & Bobot \\
\hline 1 & Tahun & Benefit & 50 \\
& $\begin{array}{c}\text { Pembuatan } \\
\text { Kapasitas }\end{array}$ & Benefit & 20 \\
2 & Mesin & Benefit & 20 \\
3 & Warna & Benefit & 20 \\
4 & Tipe & Cost & 10 \\
5 & Harga & & \\
\hline
\end{tabular}




\section{Data Sub Kriteria Pemilihan Sepeda Motor Bekas}

Data sub kriteria merupakan data penunjang yang digunakan dalam perhtungan prioritas kriteria. Data Kriteria memiliki bobot preferensi atau tingkat kepentingan dari setiap kriteria dengan nilai:

$$
\begin{aligned}
& 1=\text { sangat rendah } \\
& 2=\text { rendah } \\
& 3=\text { sedang } \\
& 4=\text { tinggi } \\
& 5=\text { sangat tinggi }
\end{aligned}
$$

Bobot yang digunakan dalam penelitian

\begin{tabular}{|c|c|c|}
\hline Kriteria & Sub Ktiteria & $\begin{array}{c}\text { Bobot Sub } \\
\text { Kriteria }\end{array}$ \\
\hline \multirow{5}{*}{$\begin{array}{c}\text { Tahun } \\
\text { Pembuatan }\end{array}$} & 2017 & 1 \\
\hline & 2016 & 2 \\
\hline & 2015 & 3 \\
\hline & 2014 & 4 \\
\hline & 2013 & 5 \\
\hline \multirow{5}{*}{ Kapasitas Mesin } & $125 \mathrm{cc}$ & 1 \\
\hline & $150 \mathrm{cc}$ & 2 \\
\hline & $200 \mathrm{cc}$ & 3 \\
\hline & $250 \mathrm{cc}$ & 4 \\
\hline & Diatas $250 \mathrm{cc}$ & 5 \\
\hline \multirow{5}{*}{ Warna } & Lainnya & 1 \\
\hline & Merah & 2 \\
\hline & Hijau & 3 \\
\hline & Putih & 4 \\
\hline & Hitam & 5 \\
\hline \multirow{5}{*}{ Tipe } & Skuter Matic & 1 \\
\hline & Motor Bebek & 2 \\
\hline & Sport Touring & 3 \\
\hline & Sport & 4 \\
\hline & Trail & 5 \\
\hline \multirow{5}{*}{ Harga } & Diatas 51 Juta & 1 \\
\hline & 41 Juta - 50 Juta & 2 \\
\hline & 31 Juta - 40 Juta & 3 \\
\hline & 21 Juta - 30 Juta & 4 \\
\hline & 10 Juta - 20 Juta & 5 \\
\hline
\end{tabular}
ini, berdasarkan hasil wawancara dengan pemilik showroom Sahabat Motor. Data sub kriteria dapat dilihat pada tabel 3.

Tabel 3. Data Sub Kriteria

\section{Simulasi Perhitungan Pemilihan Sepeda Motor Bekas dengan Metode AHP dan SAW}

Proses perhitungan AHP dilakukan untuk mendapatkan nilai bobot prioritas dari kriteria-kriteria yang ada pada showroom Sahabat Motor, dalam hal ini yang akan diuraikan adalah sepeda motor bekas. Berikut ini merupakan langkah-langkah yang dilakukan dalam melakukan proses perhitungan AHP.

Menghitung bobot kriteria pemilihan sepeda motor bekas, dengan cara sebagai berikut:

a. Elemen $a[i, j]=1$, dimulai $i=1,2,3, \ldots n$. Untuk penelitian ini $\mathrm{n}=5$.

b. Elemen matriks segitiga atas sebagai input. Pada tahap ini dilakukan penilaian perbandingan antara satu kriteria dengan kriteria yang lain. Hasil

\begin{tabular}{|c|c|c|c|c|c|}
\hline Kriteria & $\begin{array}{l}\text { Tahun } \\
\text { Pembuatan }\end{array}$ & $\begin{array}{l}\text { Kapasitas } \\
\text { Mesin }\end{array}$ & Warna & Tipe & Harga \\
\hline $\begin{array}{l}\text { Tahun } \\
\text { Pembuatan }\end{array}$ & $1 / 1$ & $3 / 1$ & $5 / 1$ & $5 / 1$ & $5 / 1$ \\
\hline $\begin{array}{l}\text { Kapasitas } \\
\text { Mesin }\end{array}$ & $1 / 3$ & $1 / 1$ & $2 / 1$ & $2 / 1$ & $2 / 1$ \\
\hline Warna & $1 / 5$ & $1 / 2$ & $1 / 1$ & $2 / 1$ & $2 / 1$ \\
\hline Tipe & $1 / 5$ & $1 / 2$ & $1 / 2$ & $1 / 1$ & $2 / 1$ \\
\hline Harga & $1 / 5$ & $1 / 2$ & $1 / 2$ & $1 / 2$ & $1 / 1$ \\
\hline
\end{tabular}
penilaian yang diperoleh dari kuisioner AHP dapat dilihat pada Tabel 4.

Tabel 4. Perbandingan berpasangan Kriteria Pemilihan Sepeda Motor Bekas 
Tabel 5. Matriks Bilangan Desimal Kriteria Pemilihan Sepeda Motor Bekas

\begin{tabular}{|l|l|l|l|l|l|}
\hline Kriteria & Tahun & Kapasitas & Warna & Tipe & Harga \\
Pahun & 1,00 & 3,00 & 5,00 & 5,00 & 5,00 \\
Pembuatan & & & & & \\
\hline Kapasitas & 0,33 & 1,00 & 2,00 & 2,00 & 2,00 \\
Mesin & & & & & \\
\hline Warna & 0,20 & 0,50 & 1,00 & 2,00 & 2,00 \\
\hline Tipe & 0,20 & 0,50 & 0,50 & 1,00 & 2,00 \\
\hline Harga & 0,20 & 0,50 & 0,50 & 0,50 & 1,00 \\
\hline
\end{tabular}

Tabel 6. Matriks Penjumlahan Kolom Kriteria Pemilihan Sepeda Motor Bekas

\begin{tabular}{|l|l|l|l|l|l|}
\hline Kriteria & $\begin{array}{l}\text { Tahun } \\
\text { Pembuatan }\end{array}$ & $\begin{array}{l}\text { Kapasitas } \\
\text { Mesin }\end{array}$ & Warna & Tipe & Harga \\
\hline Pahun & 0,52 & 0,55 & 0,56 & 0,48 & 0,42 \\
\hline Kapasitas & 0,17 & 0,18 & 0,22 & 0,19 & 0,17 \\
Mesin & & & & & \\
\hline Warna & 0,10 & 0,09 & 0,11 & 0,19 & 0,17 \\
\hline Tipe & 0,10 & 0,09 & 0,06 & 0,10 & 0,17 \\
\hline Harga & 0,10 & 0,09 & 0,06 & 0,05 & 0,08 \\
\hline
\end{tabular}

Tabel 7. Tabel Rata-Rata Setiap Kriteria (Vektor Bobot)

\begin{tabular}{|c|c|c|c|c|c|c|}
\hline Kriteria & $\begin{array}{l}\text { Tahun } \\
\text { Pembuatan }\end{array}$ & $\begin{array}{l}\text { Kapasitas } \\
\text { Mesin }\end{array}$ & Warna & Tipe & Harga & $\begin{array}{l}\text { Rata- } \\
\text { rata }\end{array}$ \\
\hline $\begin{array}{l}\text { Tahun } \\
\text { Pembuatan }\end{array}$ & 0,52 & 0,55 & 0,56 & 0,48 & 0,42 & 0,50 \\
\hline $\begin{array}{l}\text { Kapasitas } \\
\text { Mesin }\end{array}$ & 0,17 & 0,18 & 0,22 & 0,19 & 0,17 & 0,19 \\
\hline Warna & 0,10 & 0,09 & 0,11 & 0,19 & 0,17 & 0,13 \\
\hline Tipe & 0,10 & 0,09 & 0,06 & 0,10 & 0,17 & 0,10 \\
\hline Harga & 0,10 & 0,09 & 0,06 & 0,05 & 0,08 & 0,08 \\
\hline
\end{tabular}

Consistency Ratio merupakan parameter yang digunakan untuk memeriksa perbandingan berpasangan telah dilakukan dengan konsekuen atau tidak [2]. Penentuan parameter ini dalam kasus
Pemilihan Sepeda Motor Bekas dilakukan dengan proses sebagai berikut :

1) Mengalikan nilai bilangan decimal dari setiap matriks kriteria dengan eigenvector

\section{Tabel 8. Matriks Perkalian}

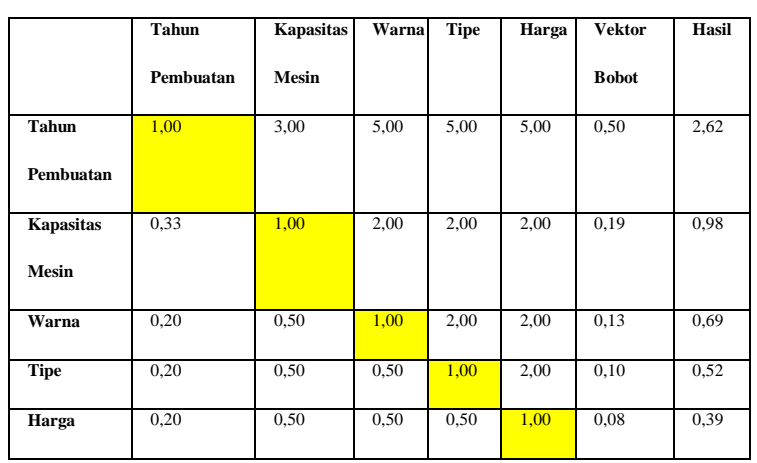

2) Menghitung Consistency Vektor dengan jalan menentukan nilai ratarata dari Weidhted Sum Vektor sebagai berikut :
2,62
$0,50=5,24$
0,98
$0,19=5,131579$
$0,69: 0,13=5,269231$
$0,52: 0,10=5,2$
$0,39 \quad: \quad 0,08=4,875$

3) Menghitung nilai rata-rata dari Consistency Vektor sebagai berikut : $\lambda=\frac{5,24+5,131579+5,269231+5,2+4,875}{5}=5,143162$

4) Menghitung Nilai Consistency Index dengan menggunakan rumus $C I=\frac{\lambda-n}{n-1} \mathrm{n}:$ banyaknya alternatif $C I=\frac{5,143162-5}{5-1}$ $C I=0,03579$

5) Menghitung Consistency Ratio, dibutuhkan nilai RI yaitu Random Index yang didapat dari tabel Oarkridge $(C R=C I / R I)$. Untuk $n=5$, nilai RI adalah 1,188 . Jadi nilai $C R$ untuk pemilihan sepeda motor bekas adalah $\quad 0,03679 / 1,188=0,030127$. Penilaian perbandingan dikatakan konsisten jika CR tidak lebih dari 0.10, sehingga penilaian perbandingan kriteria pemilihan sepeda motor bekas sudah konsisten 
dan tidak memerlukan revisi penilaian.

Tabel 9.Fungsi Kriteria Pemilihan Sepeda Motor Bekas

\begin{tabular}{lll}
\hline No & Kriteria & Fungsi \\
\hline 1 & Tahun Pembuatan & Benefit (+) \\
2 & Kapasitas Mesin & Benefit $(+)$ \\
3 & Warna & Benefit (+) \\
4 & Tipe & Benefit(+) \\
5 & Harga Beli & Cost (-) \\
\hline
\end{tabular}

Tabel 10. Matrik Awal Nilai Alternatif Pemilihan Sepeda Motor Bekas

\begin{tabular}{cccccc}
\hline \multirow{2}{*}{ Alternatif } & \multicolumn{6}{c}{ Kriteria Pemilihan Sepeda Motor Bekas } \\
\cline { 2 - 6 } & $\begin{array}{c}\text { Tahun } \\
\text { Pembuatan }\end{array}$ & $\begin{array}{c}\text { Kapasitas } \\
\text { Mesin }\end{array}$ & Warna & Tipe & Harga \\
\hline $\begin{array}{c}\text { Sepeda } \\
\text { Motor 1 }\end{array}$ & $\mathbf{0 , 3}$ & $\mathbf{0 , 2 3}$ & $\mathbf{0 , 2}$ & $\mathbf{0 , 7}$ & $\mathbf{0 , 3}$ \\
\hline $\begin{array}{c}\text { Sepeda } \\
\text { Motor 2 }\end{array}$ & $\mathbf{0 , 3}$ & $\mathbf{0 , 2 3}$ & $\mathbf{0 , 1}$ & $\mathbf{0 , 5}$ & $\mathbf{0 , 1}$ \\
\hline $\begin{array}{c}\text { Sepeda } \\
\text { Motor 3 }\end{array}$ & $\mathbf{0 , 3}$ & $\mathbf{0 , 2 3}$ & 0,7 & $\mathbf{0 , 7}$ & $\mathbf{0 , 3}$ \\
\hline $\begin{array}{c}\text { Sepeda } \\
\text { Motor 4 }\end{array}$ & $\mathbf{0 , 4}$ & $\mathbf{0 , 2 3}$ & $\mathbf{0 , 1}$ & $\mathbf{0 , 9}$ & $\mathbf{0 , 5}$ \\
\hline $\begin{array}{c}\text { Sepeda } \\
\text { Motor 5 }\end{array}$ & $\mathbf{0 , 3}$ & $\mathbf{0 , 3}$ & $\mathbf{0 , 7}$ & $\mathbf{0 , 7}$ & $\mathbf{0 , 5}$ \\
\hline Bobot & $\mathbf{0 , 5 0}$ & $\mathbf{0 , 1 9}$ & $\mathbf{0 , 1 3}$ & $\mathbf{0 , 1 0}$ & $\mathbf{0 , 0 8}$ \\
\hline
\end{tabular}

Tabel 11. Matriks Normalisasi Alternatif Pemilihan Sepeda Motor Bekas

\begin{tabular}{|c|c|c|c|c|c|c|c|}
\hline \multirow[b]{2}{*}{ Alternatif } & \multicolumn{5}{|c|}{ Kriteria Pemilihan Sepeda Motor Bekas } & \multirow[b]{2}{*}{ Total } & \multirow[b]{2}{*}{ Rangking } \\
\hline & $\begin{array}{l}\text { Tahun } \\
\text { Pembuatan }\end{array}$ & $\begin{array}{c}\text { Kapasitas } \\
\text { Mesin }\end{array}$ & Warna & Tipe & Harga & & \\
\hline Sepeda Motor 1 & 0,75 & 1 & 0,29 & 0,78 & 0,33 & 0,71 & 5 \\
\hline Sepeda Motor 2 & 0,75 & 1 & 0,14 & 0,56 & 1 & 0,72 & 4 \\
\hline Sepeda Motor 3 & 0,75 & 1 & 1 & 0,78 & 0,33 & 0,80 & 3 \\
\hline Sepeda Motor 4 & 1 & 1 & 0,14 & 1 & 0,2 & 0,82 & 2 \\
\hline Sepeda Motor 5 & 0,75 & 1,3 & 1 & 0,78 & 0,2 & 0,85 & 1 \\
\hline Bobot & $\mathbf{0 , 5 0}$ & $\mathbf{0 , 1 9}$ & $\mathbf{0 , 1 3}$ & 0,10 & $\mathbf{0 , 0 8}$ & & \\
\hline
\end{tabular}

\section{Use Case Diagram}

Use case adalah rangkaian/uraian sekelompok yang saling terkait dan membentuk sistem secara teratur yang dilakukan atau diawasi oleh sebuah actor.

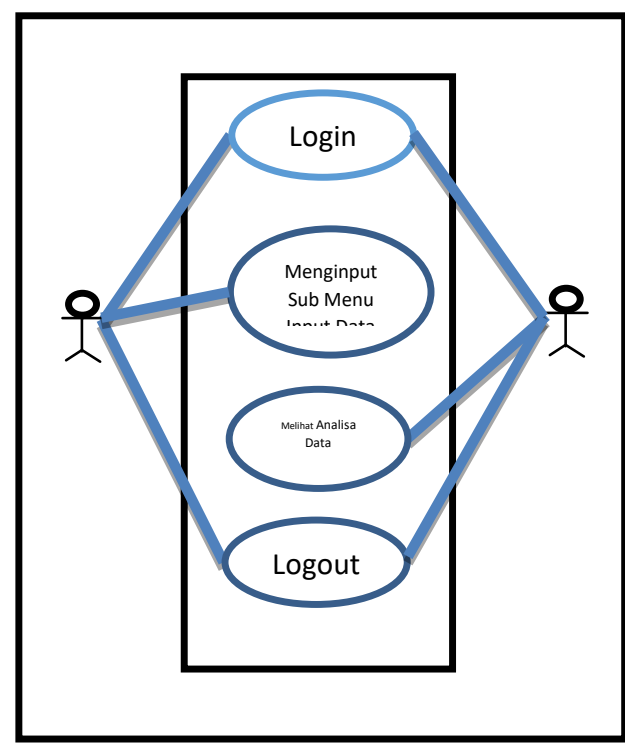

Gambar 3. Use Case Diagram

\section{Tampilan Menu Utama}

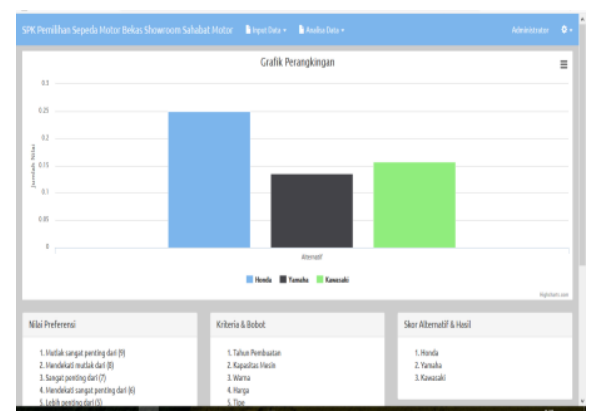

Gambar 4. Tampilan Menu Utama

Tampilan Sub Menu Input Data

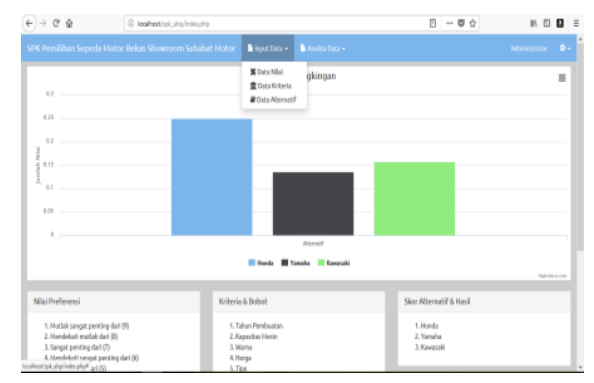

Gambar 5. Tampilan Menu Input Data 


\section{Tampilan Data Alternatif}
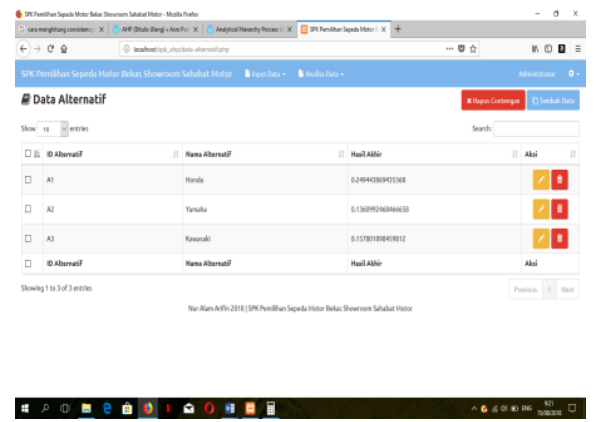

Gambar 6. Tampilan Data Alternatif

\section{Tampilan Data Kriteria}

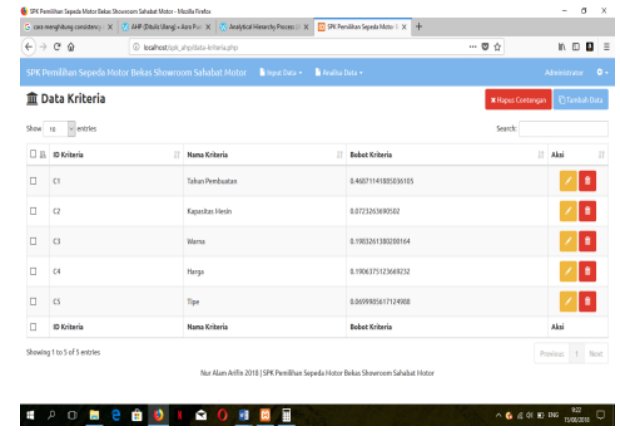

Gambar 7. Tampilan Data Kriteria

Tampilan Rangking

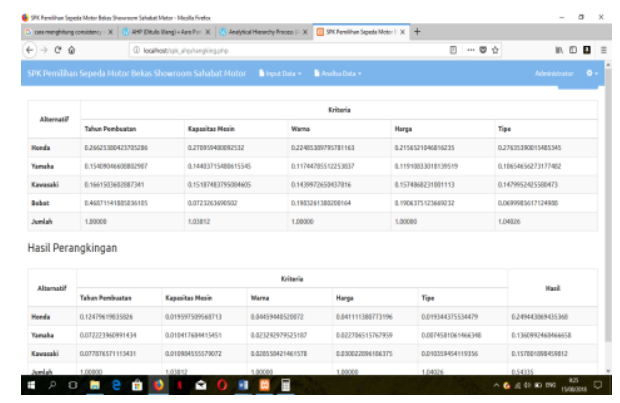

Gambar 8. Tampilan Rangking

\section{Pengujian Sistem}

Sistem yang telah dirancang perlu diuji untuk mengetahui tingkat efektifitas dan kehandalan sistem dalam menyelesaikan masalah yang ada. Selain sistem mudah digunakan, sistem juga harus dapat diterima oleh pihak-pihak yang akan menggunakan perancangan tersebut.
Dalam penelitian ini penulis menggunakan black-box testing yang dirancang untuk memvalidasi persyaratan fungsional tanpa perlu mengetahui kerja internal dari sebuah program. Teknik pengujian black-box testing berfokus pada ranah informasi dari perangkat lunak, menghasilkan test case dengan cara mempartisi ranah masukan (input) dan keluaran (output) dari sebuah program dengan cara mencakup pengujian yang menyeluruh. Black-box testing juga merupakan sebuah metode yang digunakan untuk menemukan kesalahan dan mendemonstrasikan fungsionalitas aplikasi saat dioperasikan, apakah input diterima dengan benar dan output yang dihasilkan telah sesuai dengan yang diharapkan.

Responden yang terlibat dalam Black Box Testing sebanyak 5 (lima) orang yang terdiri dari 4 (empat) orang costumer showroom sahabat motor dan 1 (satu) orang perwakilan dari staff showroom.

Tabel 12. Pengujian Kotak Hitam (Black Box Testing)

\begin{tabular}{|c|c|c|}
\hline Kelas Uji & Butir Uji & $\begin{array}{c}\text { Jenis } \\
\text { Pengujian }\end{array}$ \\
\hline \multirow{3}{*}{$\begin{array}{c}\text { Pengolahan } \\
\text { Data Kriteria } \\
\text { Pemilihan } \\
\text { Sepeda Motor } \\
\text { Bekas }\end{array}$} & $\begin{array}{l}\text { Tambah } \\
\text { Kriteria }\end{array}$ & Black Box \\
\hline & $\begin{array}{c}\text { Ubah } \\
\text { Kriteria }\end{array}$ & Black Box \\
\hline & $\begin{array}{l}\text { Hapus } \\
\text { Kriteria }\end{array}$ & Black Box \\
\hline \multirow{3}{*}{$\begin{array}{l}\text { Pengolahan Data } \\
\text { Sepeda Motor }\end{array}$} & $\begin{array}{c}\text { Tambah } \\
\text { Data Sepeda } \\
\text { Motor }\end{array}$ & Black Box \\
\hline & $\begin{array}{c}\text { Ubah Data } \\
\text { Sepeda } \\
\text { Motor }\end{array}$ & Black Box \\
\hline & $\begin{array}{l}\text { Hapus Data } \\
\text { Sepeda } \\
\text { Motor }\end{array}$ & Black Box \\
\hline
\end{tabular}

\section{SIMPULAN}

Berdasarkan hasil uraian dan analisa yang telah dijabarkan pada bab-bab sebelumnya, maka dari penelitian ini dapat disimpulkan sebagai berikut: 
1. Sistem pendukung keputusan dengan metode AHP dan SAW dapat menyeleksi sepeda motor bekas dengan cepat dan akurat sesuai dengan kriteria yang ditetapkan showroom sahabat motor.

2. Hasil pengujian model sistem pendukung keputusan menggunakan Uji Konsisten Rasio (Consistency Ratio) terhadap pemilihan sepeda motor bekas menghasilkan nilai $\mathrm{CR}$ sebesar 0,030127 sehingga dapat dinyatakan bahwa penilaian kriteria sudah konsisten, karena kurang dari 0,10 .

3. Hasil pengujian software menggunakan metode black-box menghasilkan bahwa semua pengujian terhadap sistem berdasarkan persyaratan fungsional ini dapat diterima.

\section{Saran}

Untuk penelitian yang akan datang dapat dikembangkan lebih lanjut tentang adanya kriteria baru atau menambahkan beberapa kriteria yang berpengaruh terhadap penentuan pemilihan sepeda motor bekas dalam skala lebih luas.

\section{DAFTAR PUSTAKA}

[1] Kusrini , "Konsep dan Aplikasi Sistem Pendukung Keputusan". ANDI. Yogyakarta, 2007.
[2] Marimin, M. Aplikasi Teknik Pengambilan Keputusan Dalam Manajemen Rantai Pasok. Bogor: IPB Press, 2010.

[3] Kusumadewi, dkk. "Fuzzy MultiAtribute Decision Making (MADM)". Graha Ilmu. Yogyakarta, 2006.

[4] "Additive Utilities with Incomplete Product Set : Application to Priorities and Assignments".1967.

[5] Arief M Rudianto. 2011. Pemrograman Web Dinamis menggunakan PHP dan MySQL. C.V ANDI OFFSET. Yogyakarta, 2011.

[6] Moh. Nazir. Metode Penelitian. Ghalia Indonesia. Jakarta, 1988.

[7] Presmann, R.S. "Rekayasa Perangkat Lunak". Penerbit Andi Offset, Yogyakarta, 2005.

[8] Eniyati, S. "Perancangan Sistem Pendukung Pengambilan Keputusan untuk penerimaan Beasiswa dengan Metode Simple Additive Weighting (SAW)". Jurnal Teknologi Informasi Dinamik, Vol. 16 No. 2, Juli 2011. Hal 171-177.

[9] Hermawan, S, "Mudah Membuat Aplikasi Android". Penerbit Andi Offset, Yogyakarta, 2011.

[10]Kartiko, D., "Sistem Pendukung Keputusan Pemberian Beasiswa Di PT. Indomarco Prismatama Cabang Bandung, Fakultas Teknik dan Ilmu Komputer, Universitas Komputer Indonesia, Bandung”.2010. 